\title{
INSIGHT INTO CORPORATE SOCIAL RESPONSIBILITY PRACTICES OF CZECH COMPANIES
}

\author{
Klára Kašparová and Radoslav Škapa \\ Masaryk University, Czech Republic
}

\begin{abstract}
Growing power of interest groups (stakeholders) together with legislation forces companies to have bigger social responsibility for their activities. The extent of such activities in Czech and Slovak companies is unknown, as the representative poll on this topic has not been done so far. In our paper, we explore Corporate Social Responsibility-reporting in these two countries to find out if and to what extent do the annual reports of Czech and Slovak companies include information about their CSR activities. Another task is to identify differences in CSR-reporting in Czech and Slovak companies. Besides this explorative research we have also tested hypotheses concerning linkages between CSR-reporting and (1) ownership of companies, (2) economical conditions and (3) size of companies.
\end{abstract}

\section{INTRODUCTION}

Item Corporate Social Responsibility (CSR) has been discussed by experts since the 1950 s. The year of 1953 is considered to be a breakthrough because $\mathrm{H}$. R. Bowen published his book "Social Responsibilities of the Businessman" in which he defines the first social responsibilities. The so called Iron law introduced by Davis has been in progress since the 1960 s. It says that society gives a company a certain right that could be taken back in case the company does not fulfill the expectations of the society. This idea was supported in 1970s by Committee for Economic Development. In 1980s, CSR theorists used stakeholder theory to reason target groups of CSR activities and started the debate about sustainable development.

In 1996, Jacques Delors initiated the formation of European expert centre in social responsibility of the company CSR Europe in terms of helping companies to reach their profits, sustainable long term growth and development of human capital through lying down CSR into their business activities (Gravlien et al.
2002). In 2000, CSR Europe published the standards called The Voluntary Guidelines intended to persuade companies to voluntarily inform relevant stakeholders about their social and environmental behaviour.

European committee started the real discussion on the topic of CSR in 2001 when it published its CSR definition based on triple-bottom line, which differed from well-known Carroll's definition. According to Carroll, CSR has four components: economic responsibility, legislative responsibility, ethical responsibility and voluntary responsibility. The common point of both definitions is that they count on a particular company investments in activities exceeding legal duty. It is not evident, however, what is the reason for engaging in them. It is necessary to realize that the primary goal of a company's activities is creation of profit for its owners and therefore, these activities must be repaid.

In the present day, most theoreticians and researchers agree on the fact that CSR-activities produce benefits such as increase of profit, access to supplementary capital, decrease of costs, improvement of company's image, increase of turnover and allegiance of customers, increase of productivity and quality, increase of the ability to acquire and hold effective employees, keeping up with the competition and market demands, or possible decrease of legal control and measures. At the same time, these researches have came to the conclusion that in order to become apparent, the positive effects must be published or informed about by the company.

\section{REPORTING ABOUT CSR- ACTIVITIES}

Lee, one of the authors of public relations, has already pointed out that CSR-activities might bring substantial benefits to companies but only in the case when companies promote their CSR-activities. But this is, especially in Czech Republic, very difficult because 
journalists are afraid to inform public about these activities due to fear from a hidden advertising. So companies have to use another communication channels to reach their stakeholders - primarily advertising, corporate web site and their annual reports.

CSR reports into annual corporate reports. Should we compare conclusions of researches focusing on whether companies indeed publish CSR-information as a part of their annual reports, we reach rather contradictory results. PricewaterhouseCoopers for example found out that $66 \%$ out of 992 CEO respondents publish reports on permanent development sustainability within annual corporate reports, and $26 \%$ respondents do not publish CSR reports yet, however, they plan to incorporate the information into their annual reports. This is in a sharp contrast to a research of KPMG which asserts that only a small group of companies from the sample of top 250 companies in the Global Fortune 500 chart and from the sample of top 100 companies of 16 chosen countries - incorporated CSR reports into their annual corporate reports in 2005.

As is apparent from the research of KPMG and PwC, the contents of reports gradually changes alongside with growth of interest in CSR and there is the shift from problems of safety and health towards greater emphasis on social issues, especially on community involvement and philanthropy. But KPMG research also point out that there are still vast differences in scope of informing about CSR-activities in various countries and sectors.

When researching in this area, we might come across certain paradox. On one hand, both general public and experts claim that it is necessary to publish the CSR reports, on the other hand, many surveys prove that these groups read the reports rather scarcely (Dawkins, J., 2004, p. 9). When it comes to consumers, we can observe such a feature that the standpoints adopted by them sometimes do not correspond with their behavior. Reading of a report represents a form of cost or effort which increases as the extent of a report grows. It is necessary to say that not all people are willing to pay such costs. Simultaneously, some people might adopt rather ambiguous relation towards reports coming directly from a company, as they consider such information to be a form of a hidden advertisement.

Then it is quite logical that in case they seek for such information at all, they tend to finding it in different sources than CSR reports, e. g. opinion makers, media etc. (for further information on this issue, see the Table
3). Such fears might be diminished by verification of the data presented to them by a disinterested institution. According to the research carried out by Association of Chartered Certified Accountants in 2003, such approach is chosen by $40 \%$ of companies which publish their CSR reports (Trnková, 2005, p. 81).

\section{CSR IN CZECH REPUBLIC AND IN SLOVAKIA}

In both countries, companies have started to think about impacts of their activities on society and their environment - necessary to say, not only when it comes to their legal duties. It is also NGOs, who try to improve and cultivate the enterprise culture in the Czech Republic and in Slovakia. They do so by organizing educational projects and evaluating CSRactivities in particular branches in such manner that they create various charts assessing the behaviour of companies.

\section{Situation in the Czech Republic}

Business Leaders Forum supported by European Committee carried out a research in general knowledge about CSR. On a sample of more than 100 companies it was found out that the knowledge about social responsibility (CSR) was disproportional between the companies with foreign capital and domestic capital. The research concluded that the knowledge was better in companies with foreign capital (see also hypothesis H 1). It was also found out that the media try to avoid informing about CSR-activities of companies - they do not want to be accused of hidden advertising (Trnková, 2004, p.180).

STEM agency observed suitability of individual communication channels for information about CSRreporting. In spite of what has been stated above, this research showed that the distrust of the media towards informing about CSR-activities is not an obstacle that is impossible to come over. It is interesting to notice what proved to be the most suitable channel to inform about the activities: short information on producţ̧ š $\check{r}$ Consumers themselves agreed on these to be the most suitable source of information. However, they labeled short information on products as least appropriate communication channel to form their opinion on social, ethic or ecological behavior of companies (Jeřábková, Hartl, 2003, p. 39). Nonetheless, in sociological and marketing researches, such paradoxical situations are no exceptions.

Even though the data provided by Jeřábková and Hartl are clear about the fact that presentation of companies 
through own channels (Internet, company newspapers or leaflets) is less effective than via other channels, the companies are sometimes left with these as the only possible way of reporting about their CSRactivities. The media are afraid of being accused of hidden advertisement and argue that in their reporting, they generally attempt to cover what is wanted by widest public and that the society (or the widest public) proves to be rather inattentive to such reports so far.

According to Business Leaders Forum, Czech companies see care for their employees and their education, transparency and ecology to be the most important components of CSR. Philanthropy is mentioned very rarely. When discussing real actions - not proclamations only, companies established programs of employee care; they tried to be transparent, to cooperate with universities, to provide educational programs for their employees, to cooperate with nonprofit organizations and to protect the environment respectively.

\section{Situation in Slovakia}

Similar surveys were made by Business Leaders Forum in Slovakia. The results show that Slovak population is divided into 2 parts when discussing the issue of CSR-reporting. $41 \%$ of respondents consider publishing information about CSR not to be important. On the other hand, $55 \%$ of respondents are interested in receiving information about CSR, but they are not sure of the most suitable communication channel below-the-line media (local media are more trustworthy in this case according the respondents), internet and annual reports were discussed mostly.

This research also revealed that social responsible companies should be concerned with professional development of their employees, protection of environment and philanthropy. The two last mentioned components are the key criterion of respondents when deciding whether a company is or is not socially responsible. But the ranking differed when respondents were asked to order criterions according to importance for them. Then, professional development of their employees was the first again, but the protection of the environment moved down to the fifth position. Work-life balance, honesty in business and employment of disabled people were more important than the protection of environment.

The most important components of CSR according Slovak business leaders were investigated in World Bank pilot program "Enabling a Better Environment for CSR in Central and Eastern European". The survey revealed that protection of environment, complying with the existing legal framework, protecting health of employees and ensuring job security are the main duties of companies. Only $46 \%$ of companies agree with the statement that contribution to charities is one of its main duties in society. The findings imply that perception of public and companies is not in perfect concordance in this field. In those points, there is a difference between Czech and Slovak companies' perception.

\section{RESEARCH AIMS}

As it was claimed in the previous sections of this article, the interest in CSR-reporting has grown in the Czech Republic and Slovakia. Should the CSRactivities of companies bring economic benefits to companies, it is necessary to inform their stakeholders. In our analysis, we decided to focus on information provided by company publications - the annual reports in particular. We set a research goal to find out if and to what extent do the annual reports of Czech and Slovak companies include information about CSR activities. Besides this explorative research aim, we have stated five main hypotheses to be tested:

\section{H1: The companies owned by persons or institutions from Old EU Member States often cover CSR- activities in their annual reports.}

This hypothesis is based on the survey of Business Leaders Forum which found out that the knowledge about social responsibility concept was better in Czech companies with foreign capital. The knowledge does not automatically mean action, of course. Therefore we only ask the question if companies with West European capital report about CSR more often or not. This may be indirectly answered by the question whether those companies do more CSR-activities, provided that they understand CSR better than Czech or Slovak firms.

\section{H2: The more successful a company is, the more pieces of information about CSR-activities are presented in annual report.}

The hypothesis of positive relationship between CSR and corporate financial performance was tested more times: Jawahar and McLaughlin (2001) brought up the economic situation of a company to be important limit of its CSR. In their opinion, the level of CSRactivities is affected by financial situation in previous years. Preston and O'Bannon (1997) tested this hypothesis (as well as some other ones) empirically on the data of 
67 companies within a period of eleven years. Their correlation coefficients proved a positive relation between CSR and economical situation of particular companies. Accordingly to this, we set our hypothesis $\mathrm{H} 2$ as a positive relation of economical situation and the extent of covered CSR-categories in annual reports.

We expect similar relations between CSR-reporting and economical situation; this time, however, it was defined not as economical performance but as economical power. Thus, we analyze the linkage between CSR (reporting) and the size of companies measured by revenues and number of employees. We define hypothesis H3 formally:

\section{H3: The larger companies are likely to inform about their CSR-activities more often than smaller ones.}

We expect that larger companies are more visible and their activities have larger impact on society than activities of smaller ones. Due to it they are under larger pressure of stakeholders. Because of this, they have to inform more about their all activities to content all relevant stakeholders.

The definition of CSR is not stabilized yet. That creates troubles not only for researchers who try to compare CSR activities in several countries but even for managers who are responsible for implementation of CSR activities. Therefore CSR agenda differs from country to country because managers responsible for implementation CSR understand the scope of CSR differently. Some studies show that this is probably due to culture they live in. Therefore we have to take culture into consideration, when comparing CSRreporting in the Czech Republic and Slovakia.

For our research, we utilize findings made by Kolman et al. (2003), who investigated cultural differences in Czech Republic, Slovakia, Hungary and Poland. They replicated Hofstede's research about five dimension of culture using a sample of university students. Results revealed significant cultural differences between Czech Republic and Slovakia despite long common history of these two countries. The differences were remarkable in three dimensions: individualism vs. collectivism, uncertainty avoidance and long vs. short-term

\section{EXIHIBIT 1}

\begin{tabular}{|l|c|c|}
\hline Dimension & Czech Republic & Slovakia \\
\hline Power distance & 78 & 86 \\
\hline Individualism vs. collectivism & 68 & 40 \\
\hline Uncertainty avoidance & 81 & 57 \\
\hline Masculinity vs. femininity & 81 & 127 \\
\hline Long vs. short-term orientation & 28 & 52 \\
\hline
\end{tabular}

orientation (see Exhibit 1: Cultural position of the countries by Kolman et al, 2003, p. 80).

Kolman's research showed that Slovakia is collectivistic culture whereas Czech Republic is individualistic. According Hofstede, in individualistic culture people are looking after themselves and their immediate family only whereas in collectivistic culture people are belonging to in-groups that look after themselves in exchange for loyalty (Mooij, 1998, p. 75).

We use Hall's division of the cultures - low and high context and its connection with Hofstede's dimension - in interpreting the findings. In accordance with them, collectivistic culture is high context which means that a lot of information is already shared among members of this culture, and therefore their preferred mode of communication is more informal, indirect, and often based merely on symbols or pictures and not on written texts. Individualistic culture is low context where there are less personal contacts and therefore communication must be very detailed and very explicit. A great deal of formal information is communicated in a direct way, often in written texts. Based on this finding we suppose that there will be more reporting about CSR in Czech Republic than in Slovakia, because Slovakia is a collectivist country with high context communication. We state hypothesis $\mathrm{H} 4$ formally:

H4: Concerning overall CSR-reporting, Czech companies are more active than Slovak companies.

However there are some issues that can contradict our hypothesis. Czech Republic scores high on dimension uncertainty avoidance (in contrast with Slovakia). According to Hofstede, members of such culture feel threatened by ambiguous or unknown situations and try to avoid it by creation more precise laws, rules to obey. Lee (2006) concludes that such cultures need precise definition of CSR to understand it. The vagueness of CSR might be the reason why it is difficult to apply CSR concept in such cultures. Culture dimension of time orientation makes other difference between the Czech Republic and Slovakia. The culture of the Czech Republic is short term oriented. As CSR causes cost in short time period and brings benefits in long time typically, this fact could limit application of CSR in the Czech Republic. We expect both factors to be less important for CSR reporting than the factor of low context culture in the Czech Republic and that's why the hypothesis is defined as stated above. 
In strong uncertainty avoidance culture, business tends to obey authorities while in culture with low uncertainty avoidance companies are more concerned with expectation of public (Katz et al., 2001, p. 157). It means that the role of the business in community affaire is more important there. Research made by Business Leader Forum supported that idea - Slovak companies should be more active in society in the opinion of public; besides professional development of their employees, companies should deal with philanthropy and protection of environment more intensively. That's why we suppose that reporting about philanthropy and sponsorship (respondents of Business Leaders Forum research did not made a difference between them) will be more intensive in Slovakia than in the Czech Republic.

If we combine the fact that the role of the business in community affaire is more important in a culture with low uncertainty avoidance and the fact that Slovak culture is collectivistic we can assume that volunteering be practiced as well as reported about, more often in Slovakia than in Czech Republic. In concordance with a framework and related propositions made by Katz, Swanson and Nelson we could suppose that collectivistic culture is more focused on family and local community than individualistic culture and that employee involvement with the company is more important in collectivistic culture then in individualistic culture. Based on both ideas, the hypothesis $\mathrm{H} 5$ is the following:

H5: In the CSR-reporting, Slovak companies put more stress on volunteering, sponsoring and donation than Czech ones.

\section{RESEARCH \\ METHODOLOGY}

It is somewhat risky to come to any conclusion about behaviour of companies from a content analysis of annual reports. There are several reasons for such an assertion. First, companies might not wish to inform stakeholders about companies' (bad) activities; it would not be a disadvantage for them. The second reason that prevents us from making such conclusions is the fact that annual reports are not the only communication channel for the companies. It is the Internet especially that plays the crucial role. Furthermore, some companies publish their own specialized CSR reports as well. The problems mentioned above prevent us from making strict conclusions about companies' behaviour and intentions from analysis of annual reports.
Despite of that, there are several reasons why we restricted our analysis to annual reports only and why we consider our analysis to be sensible. The first reason (conditioned by the character of this analysis as one covering large number of companies) is the fact that it is virtually impossible to cover total communication of all companies involved in this analysis. Therefore, it is necessary to choose only one communication channel. The undoubted advantage of annual reports comprises in:

- Annual reports are considered to be an important document widely connected with a high degree of credibility.

- Annual reports are intended for main stakeholders, therefore they should contain reports about CSRactivities of a company.

- Compared to web presentations which may have complex structure (usually caused by hypertext links), annual reports are quite easy to analyze.

- It is not difficult to find annual reports from previous period of time.

A content analysis of a selected sample of annual reports is the core of our survey. Based on experience of other authors (who carried out different content analyses of annual reports), we chose sentences, not signs or graphics, to be the unit of interest. Since our work has a character of a pilot research, we limited our analysis on presence or absence of individual categories. Thus the extent of individual categories within the framework of annual reports (such as number of sentences describing the given category) will be broadly limited.

We have evaluated the presence of each category in a particular annual report on the sale of zero to two, where zero implies the absence of a category in the text of an annual report. The one signals the presence of a category in a very limited extent and finally two means that a category was present and described more in detail.

For example, if the text of an annual report contained information that a particular company offers social benefits for employees, a coder classified the category by one. When an annual report mentioned examples of such benefits, it was classified by two. The number (not the summary) of ones and twos gave the score for each company - the overall Index of covered CSR-topics. 
Due to the fact that most of the foreign researches in similar field dealt with very detailed coding categories, we needed to design our own categories. We suppose that Czech and Slovak annual reports will probably not contain so much highly detailed information about CSR-activities as their foreign counterparts. This assertion is has its roots in results of researches carried out in the Czech Republic. These show that general knowledge about CSR is negligible. The same results can be found out in the research of Transparency International (Čaník and Janíková, 2006) which focused on applications of methods and tools of entrepreneurial ethics in Czech environment. We do not expect Czech and Slovak annual reports to be so extensive and detailed. This is the reason why our categories are rather rough. Yet we believe that they are sufficient and from the perspective of possibility of realisation, they are even more suitable.

We defined our categories as follows:

- A defined strategy of environment protection

- Activities of environment protection

- Innovation leading towards greater utilization of sources used

- A defined strategy in social sphere

- Health and safety of employees

- Prizes awarded in the fields of ecology, care about employees

- Equal opportunities and procedures which should guarantee them

- Benefits provided to employees

- Anti-bribery policy

- Innovation resulting in improved satisfaction of customers

- Product and service quality

- Donation

- Sponsorship

- Volunteering

- Partner programmes

The coding procedure itself was conducted by one of the authors. It is obvious that the analysis done in this way has to suffer from certain subjectivism of the results. Despite of that we believe the major outcomes of our research are valid. Our conviction stems from the character of the coding scale. In most cases, it was not difficult decide if a category was present or absent.

However, the matter of subjectivity played its part in the decision whether a category was present in limited or detailed extent. Therefore we admit that those results might be distorted by the subjective opinion of a coder. To avoid (or at least to limit) the subjective character of this part of analysis, more detailed coding categories have to be set in the future. The participation of more coders is other measure, which should increase reliability of results.

\section{RESULTS OF THE ANALYSIS}

We analysed 52 Czech and 30 Slovak annual reports of public companies. All reports covered the situation in the year of 2005. Non company has covered all 15 categories we have defined in our content analysis. In Slovak companies, Doprastav was the best covering 9 out of 15 observed topics. Softip and Slovalco reached second and third position. The companies are operating in construction building, ICT and mining, respectively. Among Czech companies, Pražská energetika a.s. and Komerční banka a.s. (KB) achieved the highest score - both with ten categories covered. Pražská energetika surpassed KB because our final ranking took into account the extent of information presented as well - Index of covered CSR-topics. It is not surprising that four of the Czech TOP10 companies work in utilities (Pražská energetika, ČEZ, Mero ČR, Jihomoravska plynarenská), whereas KB a.s. and ČSOB a.s. are large banks. Zentiva a.s is a pharmaceutical firm; Telefonica is a company representing the telecomunication and Skoda Auto a.s. automotive industry. Intuitively, these results support our hypothesis H3.

The frequencies of each category can be depicted from the Exhibit 2 and 3. Each bar represents the percentage of annual reports (in our sample) containing particular category. Thus, Activities of environment protection (64\%) and Product and service quality (61\%) are the topics mentioned most often in the Czech Republic. In their research financed by Philip Morris, Je?ábková and Hartl found out that the public believes that in order to be socially responsible, a company is bound to provide quality products for a reasonable price. Perhaps this is why the companies inform about the quality of their goods together with the "evergreen" - the ecology. Other topics lie far behind - $A$ defined strategy of environment protection appeared in 36 per 
cent of cases, Benefits provided to employees in $33 \%$ and Sponsorship in $31 \%$.

Generally speaking, Czech companies included in our sample tend to inform about environmental issues very often, yet it is rather difficult to find data about other social-responsibility-activities in annual reports. Benefits provided to employees and Sponsoring \& Donation are the exceptions. Anti-bribery activities or equal opportunities of women and members of minorities remain out of focus. The survey made on the sample of foreign companies in the Czech Republic carried out in 2004 by Gender Studies, o. p. s. (2004, 18 ) reached similar results. Approximately a half of the companies included in the research were active in environmental protection. Most companies also considered exceptional working conditions for their employees to be important. In contrast with this, it was found that only insignificant number of companies tries to improve life conditions of people living in companies' surrounding. However, more than half of the companies included in that research co-operated with schools or educational institutions. This is in a contradiction with our survey.

Exhibits 2 and 3 contain extra information that shed more light into quality of each category. The darker part of bars depicts share of companies, which

\section{EXIHIBIT 2}

Presence of CSR topics in annual reports of 52 Czech companies measured in per cents. (Authors)

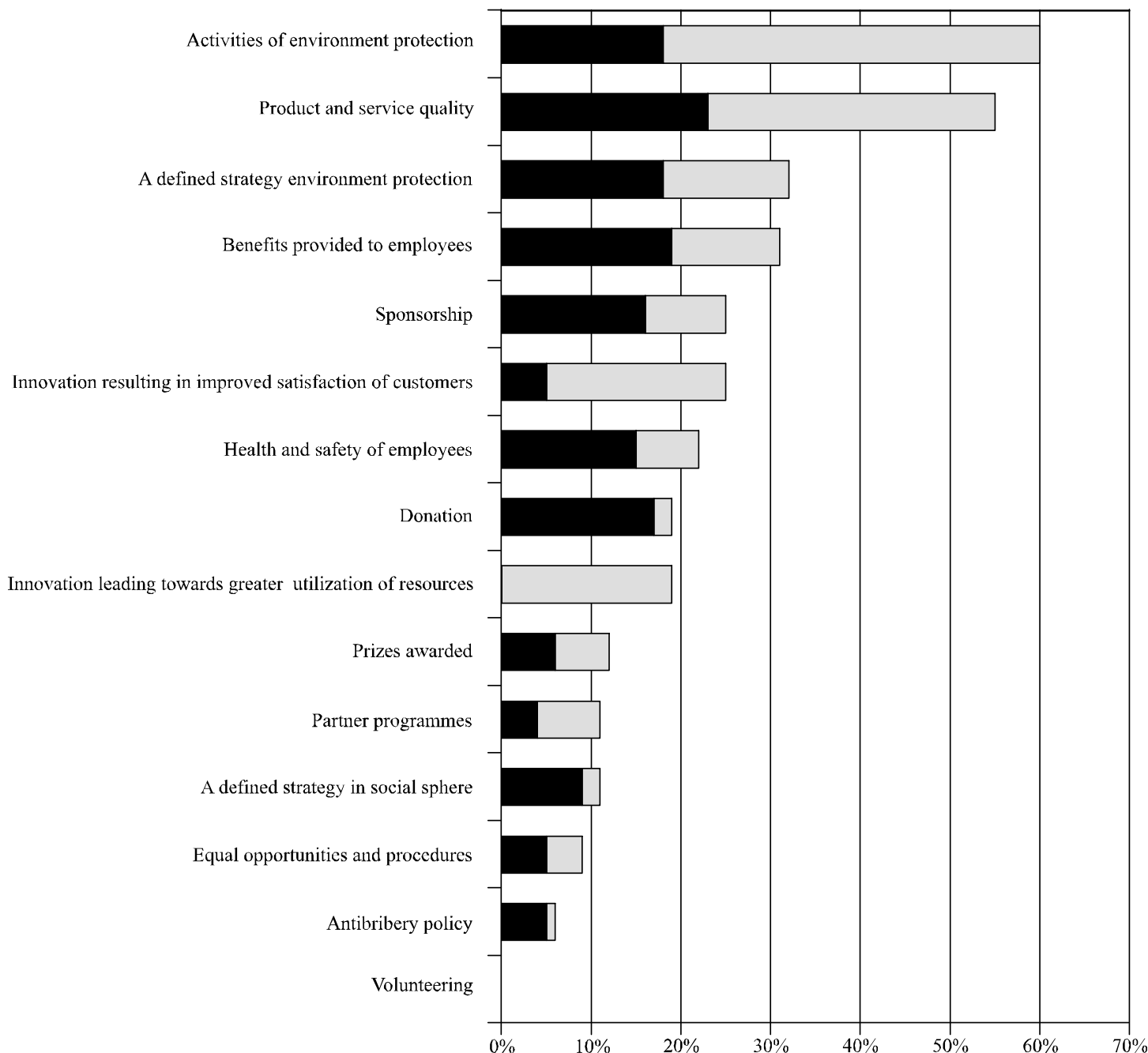

Now, we need to test the hypothesis $\mathrm{H} 4$ to answer the question, whether Czech companies are more active in CSR-reporting than Slovak companies. We compare the number of CSR-topics (number of our categories) covered in annual reports, as well as calculated Index of covered CSR-topics. Statistical t-tests did not support hypothesis H4. Speaking statistically, there is no difference in CSR-reporting in Czech and Slovak companies. 


\section{EXIHIBIT 3}

Presence of CSR topics in annual reports of 30 Slovak companies measured in per cents. (Authors)

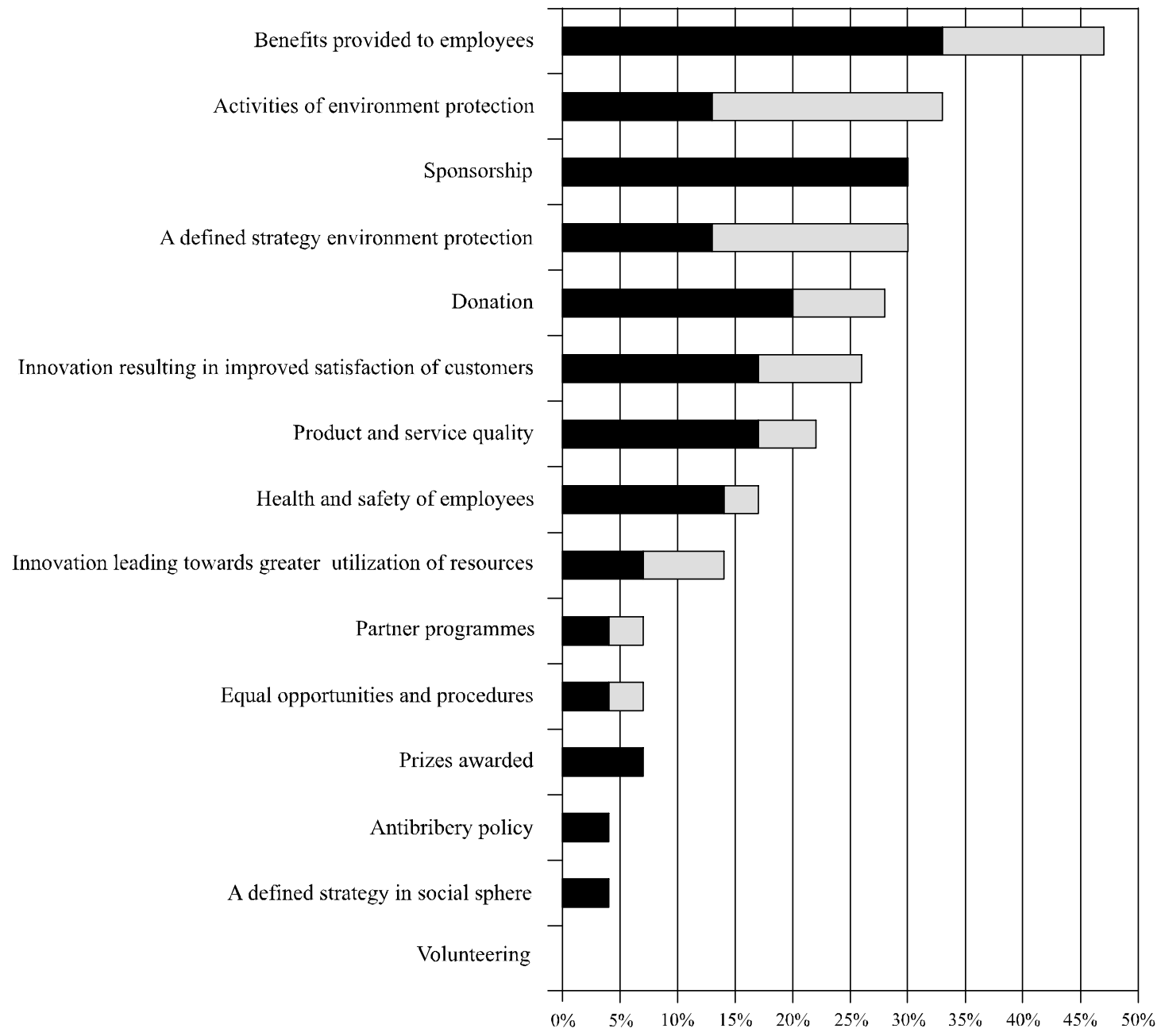

However, the result for Slovak companies differs from Czech ones in prominence of categories, namely in categories of Sponsorship, Benefits provided to employees, Donations and Product and service quality (see different position in Exhibit 2 and 3). Relative importance of Sponsorship and Donations categories is substantially higher in Slovak firms - they take third and fifth position, whereas it is fifth and eighth in Czech firms. Donations are more important relatively as well as absolutely. This category is more frequent in Slovak companies than in Czech ones $(\mathrm{t}=3,15$, Pvalue $=0,001)$. Although the category of volunteering remains neglected in both Czech as well as Slovak companies, we can conclude that our data support hypothesis H5. Slovak companies put more stress on sponsoring and donation in their CSR-reporting. High frequency of Benefits provided to employees on one hand, and low frequency of Product and service quality on the other, is surprising. In a culture with lower uncertainty avoidance, employee fluctuation is usually higher. In case of Slovakia, the culture is combined with strong masculinity as well. Both factors can explain the emphasis put on employee benefits (Kolman et al., 2003)

To answer the question of hypothesis H1, we divided our sample into two groups of companies. First group consisted of 29 firms with majority of ownership belonging to subjects (persons or institutions) located in the Old EU-Member States. The other group contained 53 companies with majority of Czech, Slovak, Hungarian or Polish owners (i.e. New EUMembers).

Assuming the normal distribution of data, we run ttests to compare the means of the two groups. We did these in each coded category as well as in overall Index of covered CSR-topics. The tests supported the hypothesis H1 - we can say that companies 
owned by persons or institutions from Old EU Member States inform more often about CSRactivities in their annual reports. This is caused by following categories, which are more frequent in annual reports of companies owned by institutions from Old EU Member States ( $\mathrm{p}$-values of t-tests were less than 0,01, resp. 0,05 in case of Antibribery policy): Partner programmes, Sponsorship, Innovation leading towards greater utilization of resources and Antibribery policy.

The hypothesis $\mathrm{H} 2$ assumed a positive relation between the extent of information about CSR and the financial situation of companies. Financial or economical situation can be measured and expressed in many ways. We chose Return On Equity (ROE) to be our indicator because of its simplicity of calculation and interpretation. ROE reflects the financial performance of a company in point of view of its owners. We can assume that good economical results (ROE) support the willingness of owners to invest into CSR, or at least the good results will diminish reluctance of owners to do so. ROE was calculated from profit after interest and tax.

The mean of calculated ROEs was rather high (26\%) due to some outliers, which we removed before calculating the statistics. Median of ROEs was $9,5 \%$. Several companies showed negative ROE, because of their negative profit (loss) or negative equity in balance sheet. We used Pearson correlation and Spearman rank correlation to find out the relationship between ROE of a company and extent of its CSRreporting (i.e. Index of covered CSR-topics). All correlation were statistically insignificant doesn't matter if it was calculated on Index-level or on level of each category. The hypothesis $\mathrm{H2}$ was rejected: Our data don't give us indication about successfulness of companies and their CSRreporting intensity.

In the last step, we explored the linkage of CSRreporting to the factor of companies' size. We utilized two indicators of size - revenues and number of employees. We have calculated Spearman and Person correlations; whereas revenues' correlation is medially strong (Spearman correlation is 0,48 and $p=0.00$ ), the correlation with number of employees is strong (Spearman correlation is 0,69 and $p=0.00$ ). Based on our results, we cannot reject your hypothesis $\mathbf{H 3}$. Our data show that larger companies inform more intensively about their CSR-activities than smaller ones. This also supports the idea of Jawahar and McLaughlin (2001) who basically claim that it is the large companies that work on CSR to greater extent.

\section{CONCLUSIONS}

The ambition of our text was to shed light onto practices of Czech and Slovak companies in the field of CSRreporting. Not being able to find any information about this subject, we decided to conduct a small, rather explorative research of CSR. In the beginning we planned to analyze content of CSR reports of companies. Unfortunately, we found only limited number of specialized CSR-reports. Therefore we decided to shift focus of our analysis to annual reports.

We verified our hypotheses by means of our Index of CSR-reporting. First conclusion is that smaller and economically weaker companies inform less about CSR. We assume that they probably don't pay attention to CSR-activities in their practice. Secondly; the environmental protection is mentioned very often compared to other CSR-topics, by Czech as well as by Slovak companies. On the other hand, information about anti-bribery activities or equal opportunities of women and members of minorities remain out of focus. Our data support the hypothesis about the differences between Czech and Slovak companies: Czech companies inform about their CSR activities more often and there is also difference in topics which they present in annual reports. For example, Slovak companies put more stress on donation and sponsoring. We substantiated this fact by factor of cross cultural differences.

Another interesting finding is about the influence of nationality of owners. Our analysis supports the idea about more intensive CSR reporting by companies of "West European" owners. This is in accordance with findings of Business Leader Forum about better knowledge of CSR-concept in foreign companies in the Czech Republic. Of course, knowledge does not necessarily mean action and reporting.

The only hypothesis that was not supported by our data was H5. Linkage between CSR-reporting and economical performance could not be proven. We cannot say that profitable companies report about CSR more often. The finding is in some contradiction with Preston and O'Bannon research (1997). The reason for that may be that we used financial data from the same year as annual reports, whereas Preston and O'Bannon used financial results from the following year. Thus, we didn't take time-leg into account. But we have to point out that researches are not unified in this matter - others experts assume that the influence is in opposite way - CSR activities may increase profit in the future. To test such feedback loops, we have to replicate our analysis with older as well as with newer financial results of companies. 
Speaking about further research, we see two directions to follow. The first one is to add other communication channels in the analysis to get broader view. Future analysis should also monitor CSR reports, Internet presentations, textual messages printed on products (besides annual reports). Special attention should be paid to independent (that is non-company) media analysis. Another possible direction of future research is to focus on SMEs, because in our current research we presumed that CSR is expected only from big companies. Nowadays, we can observe CSR reporting by medium companies as well. This tendency is reinforced by EU that sees CSR reporting as a new measure to improve competitiveness of SME.

\section{REFERENCES}

Business Leaders Forum. (2006), Spoločenská zodpovednost'firiem. Vnímanie obyvatelmi Slovenska, http:/www.blf.sk/tmp/asset_cache/link/0000013586 /CSR_sprava_2006_fin.pdf [Accessed 10. 1. 2007].

Čaník, P. and Čaníková, P. (2006), Aplikace metod a nástrojů podnikatelské etiky, Transparency International Czech Republic, Praha, Czech Republic.

Carroll, A. B. (1999), Corporate Social ResponsibilityEvolution of a Definitional Construct, Business and Society, 3, pp. 268-295.

Dawkins, J. (2004), The Expert Perspective: Views of Corporate Responsibility among NGOs and CSR Commentators, http://www.ipsosmori.com/publications/jld/the-expert-perspective.pdf [Accessed 16.6. 2006].

Gravlien, Vilsted, Hoyer, Holden. (2002), Technical Report-CSR Management System, http://www.vestforsk.no/dok/publikasjonar/rapport1802.pdf [Accessed 27. 6. 2005].

Jawahar, I. M. and McLaughlin, G. L. (2001), Toward a descriptive stakeholder theory: an organizational life cycle approach, The Academy of Management Review, 3, pp. 397-414.

Jeřábková, V. and Hartl, J. (2003), Společenská odpovědnost firem, Kladno, AISIS, Czech Republic.

Katz. J. P., Swanson D. L., Nelson, L. K. (2001), Culture-based expectations of corporate citizenship: A propositional framework and comparision of four cultures, International Journal of Organizational Analysis, 9, pp. 149-171.

Kolman, L., Noorderhaven, N. G., Hofstede, G. Dienes, E. (2003), Cross-cultural differences in Central Europe, Journal of Managerial Psychology, 18, pp. 76-88.

KPMG International. (2005), KPMG International Survey of Corporate Responsibility Reporting, http://www.kpmg.com/NR [Accessed 14. 8. 2006].

Lee, Y. J. (2006), Corporate Social Responsibility. In the Globalisation Era: Localisation or Globalisation?, http://www.sis.utk.edu/docs/misc/lee.pdf [Accessed 14. 2. 2007]. 
Mooij, M. K. de. (1998), Global marketing and advertising: understanding cultural paradoxes, Oaks, SAGE Publications, $316 \mathrm{p}$.

Preston, L. E. and O'Bannon, D. P. (1997), The Corporate Social-Financial Performance Relationship. A Typology and Analysis. Business and Society, 4, pp. 419-429.

PricewaterhouseCoopers International. (2006), CEO Survey - Leadership, Responsibility, and Growth in Uncertain Times, http://www.pwcglobal.com/ gx/eng/ins-sol/survey-rep/ceo6/pwc_6_ceo_survey.pdf [Accessed 14.8.2006].

The World Bank. (2005), What Does Business Think about Corporate Social Responsibility? Part ii: a comparison of attitudes and practices in Hungary, Poland and Slovakia, http://www.blf.sk/tmp/ asset_cache/link/0000012962/Podnikatelia\%20o\%2 0CSR\%20en.pdf [Accessed 12. 12. 2006].

Trnková, J. (2004), Společenská odpovědnost firem - kompletní prưvodce tématem \& závěry z prízkumu v ČR, Praha, http://www.blf.cz/csr/cz/vyzkum.pdf [Accessed 1. 2. 2005].

Trnková, J. (2005), Měření a reportování společenské odpovědnosti firem, in Naprríč společenskou odpovědností firem, AISIS, Kladno, pp. 76-82. 